\title{
China's crop productivity and soil carbon storage as influenced by multifactor global change
}

\author{
WEI REN*, HANQIN TIAN*, BO TAO*, YAO HUANG $†$ and SHUFEN PAN* \\ *International Center for Climate and Global Change Research, and School of Forestry and Wildlife Sciences, Auburn University, \\ Auburn, AL 36849, USA, †State Key Laboratory of Vegetation and Environmental Change, Institute of Botany, Chinese Academy \\ of Sciences, Beijing, 100093, China, $\$$ State Key Laboratory of Urban and Regional Ecology, Research Center for Eco-Environmental \\ Sciences, Chinese Academy of Sciences, Beijing, 100085, China
}

\begin{abstract}
Much concern has been raised about how multifactor global change has affected food security and carbon sequestration capacity in China. By using a process-based ecosystem model, the Dynamic Land Ecosystem Model (DLEM), in conjunction with the newly developed driving information on multiple environmental factors (climate, atmospheric $\mathrm{CO}_{2}$, tropospheric ozone, nitrogen deposition, and land cover/land use change), we quantified spatial and temporal patterns of net primary production (NPP) and soil organic carbon storage (SOC) across China's croplands during 1980-2005 and investigated the underlying mechanisms. Simulated results showed that both crop NPP and SOC increased from 1980 to 2005 , and the highest annual NPP occurred in the Southeast (SE) region $\left(0.32 \mathrm{Pg} \mathrm{C} \mathrm{yr}^{-1}, 35.4 \%\right.$ of the total NPP) whereas the largest annual SOC (2.29 $\mathrm{Pg} \mathrm{C} \mathrm{yr}^{-1}, 35.4 \%$ of the total SOC) was found in the Northeast (NE) region. Land management practices, particularly nitrogen fertilizer application, appear to be the most important factor in stimulating increase in NPP and SOC. However, tropospheric ozone pollution and climate change led to NPP reduction and SOC loss. Our results suggest that China's crop productivity and soil carbon storage could be enhanced through minimizing tropospheric ozone pollution and improving nitrogen fertilizer use efficiency.
\end{abstract}

Keywords: China, cropland, dynamic land ecosystem model (DLEM), multifactor global change, net primary productivity (NPP), soil organic carbon (SOC)

Received 17 January 2012; revised version received 17 April 2012 and accepted 18 April 2012

\section{Introduction}

Agriculture plays a vital role in ensuring food security as well as regulating climate change. Recent studies show that the vulnerability of agricultural production has been compounded due to rapid environmental changes, such as climate change (i.e. heat waves, floods and droughts) (Lal, 2004; Godfray et al., 2011; Lobell et al., 2011) and air pollution (e.g. ozone pollution) (Felzer et al., 2005; Ren et al., 2011a). Some studies also indicate that crop production can be increased and croplands could act as a carbon (C) sink by optimizing soil management practices (Paustian et al., 1997; Janzen et al., 1998; Schimel et al., 2000; Bondeau et al., 2007). Thus, to fully understand the role of agricultural carbon budget, it is required to consider impacts of multiple environmental changes and their interactions from a system-level perspective (Tian et al., 2011a). Crop net primary production (NPP) and soil organic carbon storage (SOC) are two key variables that are used to

Correspondence: Dr Hanqin Tian, School of Forestry and Wildlife Sciences, Auburn University, 602 Duncan Drive, Auburn,

AL 36849, USA, tel. +1 334844 1059, fax + 1334844 1084,

e-mail: tianhan@auburn.edu describe ecosystem production and $\mathrm{C}$ sink capacity in agricultural ecosystems, respectively. However, little is known about the magnitude and variations of crop NPP and SOC at large scale and their responses to multiple environmental changes, which is essential to understand the sustainability and vulnerability of agricultural ecosystems in the context of multiple global changes.

Both natural and human-induced environmental changes have broadly influenced NPP and SOC in intricate ways, because the various environmental stresses tend to interact with each other and exert a combined impact on ecosystem functioning (Schindler, 2001). For example, global warming with plenty of rainfall can lead to carbon accumulation in vegetation $C$ pool through enhanced photosynthesis (Cao \& Woodward, 1998), or more carbon release from soil C pool through elevated soil respiration rate (Melillo et al., 1993; Grant \& Nalder, 2000; Vukicevic et al., 2001; Scheller \& Mladenoff, 2007). Land-cover/land-use change (LCLUC) was recognized as the most important factor in enhancing or reducing total crop NPP and SOC through expanding or shrinking arable land areas, which in turn may lead to changes in physical and 
chemical soil characteristics, ecosystem structure and functioning, and microclimate (Islam \& Weil, 2000; Post \& Kwon, 2000). Nitrogen deposition/fertilizer application could result in increases in NPP and C storage in nitrogen-limited ecosystems (Schindler \& Bayley, 1993; Holland et al., 1997; Neff et al., 2000; Matson et al., 2002) or could lead to a NPP reduction in nitrogensaturated ecosystems (Magill et al., 2000). Similarly, elevated tropospheric ozone $\left(\mathrm{O}_{3}\right)$ concentrations could reduce crop yields and wood production through direct or indirect influences on photosynthesis and stomata conductance (Farage et al., 1991; Tjoelker et al., 1995; Pell et al., 1997; Martin et al., 2000; Wittig et al., 2007; Booker et al., 2009; Avnery et al., 2011). When combined with extreme climate conditions (e.g. drought) or intensive management (i.e. excessive fertilizer application), $\mathrm{O}_{3}$ pollution can reduce more NPP and $\mathrm{C}$ storage (Felzer et al., 2005; Ren et al., 2011b). Therefore, it is of critical importance to conduct a comprehensive regional assessment of the impacts of the multiple environmental changes on NPP and C storage in agricultural ecosystem and to probe the underlying mechanisms.

A significant amount of work has been conducted to investigate regional NPP and C storage and their responses to various environmental changes (Melillo et al., 1993; Houghton, 1999; Cao et al., 2003; Running et al., 2004; Felzer et al., 2004, 2005), but efforts have either simplified or ignored the input from the involved agricultural ecosystems. Several recent studies have attempted to investigate carbon dynamics in agricultural ecosystems on a large scale by using inventory, remote sensing, and ecological models (Schimel et al., 2000; Tao et al., 2005, 2009; Huang \& Sun, 2006; Huang et al., 2007, 2009; Bondeau et al., 2007; Russell et al., 2009; Wang et al., 2010; Lobell et al., 2011). For example, based on a large number of observations from longterm Chinese agro-ecosystem experiments over the period of 1977-2006, Wang et al. (2010) found that fertilization under different schemes could enhance cropland's topsoil SOC. Using a modeling method on a global scale, Lobell et al. (2011) explored that recent climate trends (increasing temperature from 1980-2008) could reduce crop yields, which even can partially offset the increase in average yields derived from technology, $\mathrm{CO}_{2}$ and other factors in some countries. In general, very few studies have attributed the relative contributions of natural and human-induced environmental changes in the context of global change. Such work cannot be easily conducted by using controlled experiments, survey, and statistical models due to the spatial heterogeneity and complex interactions and feedbacks among the various ecosystems processes (Ollinger et al., 2002; Luo \& Weng, 2011). However, integrated process-based ecosystem models that include the bio- geochemical and physiological responses of ecosystems to atmospheric and climate changes, have been proved to be a powerful tool in such multiple stress studies, especially over large regions (Bondeau et al., 2007; Huang et al., 2009; Tao et al., 2009).

In this study, we applied the agricultural module of Dynamic Land Ecosystem Model (DLEM-Ag, Tian et al., 2011a; Ren et al., 2011a) to investigate the effects of multiple environmental factors on NPP and SOC in China's croplands during 1980-2005. DLEM-Ag has the ability to simulate crop growth, hydrological, and biogeochemical cycles within agricultural ecosystems; it is also able to address consequences of land conversion from nature ecosystems to agricultural ecosystem. DLEM-Ag considers both the influences of natural environmental factors (e.g. climate, atmospheric $\mathrm{CO}_{2}$, $\mathrm{O}_{3}$ ) and land management practices (e.g. fertilizer, irrigation, rotation and so on) (Ren et al., 2011a).

China's croplands, accounting for $7 \%$ of the world's arable land, support $22 \%$ of the world population. In the recent decades, China's agricultural ecosystems have been affected by a complex set of environmental problems derived from climate, chemical composition of the atmosphere (e.g. $\mathrm{CO}_{2}$, tropospheric $\mathrm{O}_{3}$, nitrogen deposition), changes in land usage (such as land cover change), and land management practices (e.g. fertilizer and irrigation use) (Tian et al., 2011a). As one of the most intensively studied regions in the world, substantial data concerning crop distribution, soil properties, farming practices, climate, and LCLUC have been available for building long-term and high resolution regional databases (e.g. Liu et al., 2005; Yan et al., 2005; Lu and Tian, 2007; Ren et al., 2007; Liu \& Tian, 2010). These datasets can be used to drive DLEM-Ag for simulating crop NPP and SOC in responses to multiple environmental changes. The objectives of this study are (1) to analyze the spatial and temporal patterns of crop NPP and SOC in the context of global change during 1980-2005; (2) to attribute the relative contributions of major environmental factors to crop NPP and SOC, respectively.

\section{Materials and methods}

The agricultural module of the dynamic land ecosystem model (DLEM- $A g$ )

The DLEM-Ag was recently developed based on the DLEM model (Tian et al., 2010b, 2011a,b, 2012; Ren et al., 2011a). DLEM is a highly integrated process-based ecosystem model that simulates the fluxes and storage of carbon, water, and nitrogen among and within the various terrestrial ecosystem components that are driven by multiple natural and anthropogenic perturbations (e.g. climate change, $\mathrm{CO}_{2}$ concentration, 


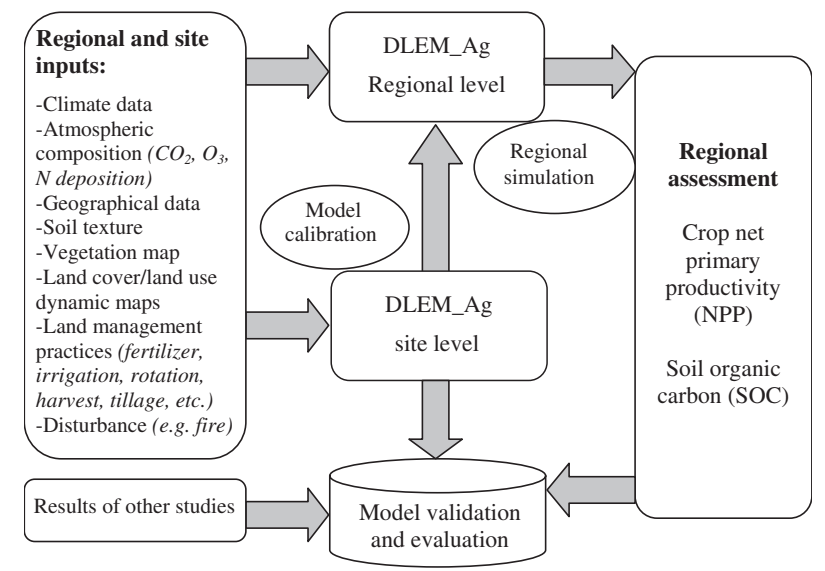

Fig. 1 Flow chart for this study.

atmospheric composition, and land use and management practices), working at multiple temporal and spatial scales. DLEM has been used extensively for the studies of the terrestrial carbon cycle and of the global changes, and the detailed model structure and processes are well documented in previous work (Tian et al., 2010b, 2011a,b; Ren et al., 2011a; Lu et al., 2012; Xu et al., 2010). DLEM-Ag can simulate daily crop growth and exchanges of trace gases $\left(\mathrm{CO}_{2}, \mathrm{CH}_{4}\right.$ and $\left.\mathrm{N}_{2} \mathrm{O}\right)$ between agroecosystems and the atmosphere. More detailed information about the features of the DLEM-Ag can be found in Ren et al. (2011a).

In this study, using the calibrated and validated DLEM-Ag (Fig. 1), we examined the transient responses of crop NPP and SOC to historical, multiple environmental stresses in China's croplands during 1980-2005. The calculations of NPP and SOC in the DLEM-Ag are described below.

NPP. We calculated NPP as the difference between gross primary production (GPP) and plant respiration $\left(\mathrm{R}_{\mathrm{A}}\right)$.

$$
\mathrm{NPP}=\mathrm{GPP}-\mathrm{R}_{\mathrm{A}}
$$

GPP. A modified Farquar's model (Farquhar et al., 1980) is used to simulate GPP ( $\mathrm{g} \mathrm{C} \mathrm{m}^{-2}$ day $\left.^{-1}\right)$, which is calculated by scaling leaf assimilation rates $\left(\mu \mathrm{mol} \mathrm{CO}_{2} \mathrm{~m}^{-2} \mathrm{~s}^{-1}\right)$ up to the whole canopy. The canopy is divided into sunlit and shaded layers.

$$
\mathrm{GPP}_{\mathrm{a}}=\mathrm{GPP}_{\mathrm{o}} f(\mathrm{PAR}) f(\mathrm{~T}) f(\mathrm{P}) f\left(\mathrm{CO}_{2}\right) f\left(\mathrm{O}_{3}\right) f(\mathrm{~N}) f(\mathrm{Veg} \mathrm{T})
$$

where $\mathrm{GPP}_{\mathrm{a}}$ is the actual GPP derived from the potential GPP $\left(\mathrm{GPP}_{\mathrm{o}}\right)$ under optimized conditions $\left(\mathrm{GPP}_{\mathrm{o}}\right)$ adjusted by environmental factor scalars that directly or indirectly influence carbon assimilation and allocation, including photosynthetically active radiation $f(\mathrm{PAR})$, climate variability/change including temperature $f(\mathrm{~T})$ and precipitation $f(\mathrm{P})$, atmospheric $\mathrm{CO}_{2} f\left(\mathrm{CO}_{2}\right)$, tropospheric $\mathrm{O}_{3} f\left(\mathrm{O}_{3}\right)$, nitrogen availability $f(\mathrm{~N})$ related to nitrogen deposition and nitrogen fertilizer application, and vegetation types $f(\mathrm{VegT})$ controlled by land cover and land use change. DLEM-Ag also considered the effect of $\mathrm{O}_{3}$ exposure on photosynthesis at the leaf level. At the canopy level, we added another response of total plant nitrogen concentration and soil nitrogen availabilities to photosynthesis besides leaf nitrogen concentrations. The detail information can be accessed in our previous studies (Ren et al., 2007; Lu et al., 2012; Tian et al., 2011a). $\mathrm{R}_{\mathrm{A}}$ Plant respiration $\left(R_{A}\right)$ in the DLEM-Ag represents total respirations of growth (construction) $\left(R_{g}\right)$ and maintenance $\left(R_{m}\right)$. $25 \%$ of assimilated C is supposed to be used as growth respiration. Maintenance respiration is a metabolic photosynthate-consuming process for maintaining existing biomass and related to nitrogen content and temperature and growth season (Ryan, 1991). The daily maintenance respiration is calculated as:

$$
\begin{aligned}
R_{m} & =r_{m} b_{g} N f_{(T)} \\
f(T) & =\mathrm{e}^{308.56 \times\left(\frac{1}{56.02}-\frac{1}{T+46.02}\right)} \\
b_{g} & = \begin{cases}1 & \text { for growing season } \\
0.5 & \text { for nongrowing season }\end{cases}
\end{aligned}
$$

where $f(T)$ is a factor controlled by temperature (Lloyd \& Taylor, 1994); $b_{g}$ is adjust factor for the growing season defined as the daily average temperature is greater than minimum temperature requirements and Leaf Area Index (LAI) greater than $0.05 ; r_{m}$ is respiration rate $\left(\mathrm{g} \mathrm{C} \mathrm{g} \mathrm{N}^{-1} \mathrm{M}^{-2}\right.$. day $\left.{ }^{-1}\right)$ at $10{ }^{\circ} \mathrm{C}$; $N$ is the nitrogen content for each carbon pool except deadwood $\left(\mathrm{g} \mathrm{N} \mathrm{M}^{-2}\right)$; $\mathrm{T}$ is daily average temperature for aboveground organs (leaf and stem) and daily soil temperature for belowground organs (roots). To sustain plant growth in simulation process, we assume that the maximum total maintenance respiration cannot be bigger than $22 \%$ of GPP when LAI is less than 1.0 and carbon storage is less than minimum storage requirement. Growth respiration is the energy cost of constructing organic compounds and the daily $\mathrm{Rg}$ is estimated as $25 \%$ of GPP in DLEM (Ryan, 1991; Thornley \& Cannell, 2000).

SOC. Soil organic matter (SOM) pools in croplands are considered with different decomposition base rates: very active $\left(\mathrm{SOM}_{\mathrm{v}}\right)$, middle active $\left(\mathrm{SOM}_{\mathrm{m}}\right)$, resistant $\mathrm{SOM}\left(\mathrm{SOM}_{\mathrm{r}}\right)$, plus one pool of dissolved organic carbon (DOC). The balance of SOM depends on the transformation of litter (LIT) to SOM, the fractions of conversion of GPP to DOC, the returned organic matter from production decay (e.g. manure), the growth of microbe, the methane production from DOC, and the decomposition rate.

$$
\begin{aligned}
& \frac{d \mathrm{C}_{\mathrm{SOM}}}{d t}= k_{\text {tr }} \text { LITC }_{\text {loss,dec }}+k_{\text {gppdoc }} \mathrm{GPP} \\
&+k_{\text {trprd }} \text { PRD }_{\text {decom }}-k_{\mathrm{rh}} \text { SOMC }_{\text {decom }} \\
&-k_{\text {luccsomcrt }} \mathrm{C}_{\text {som }}-\text { DOC }_{\text {loss,microb }} \\
&- \text { DOC }_{\text {loss,methane }} \\
& \text { SOMC }_{\text {decom }}=\sum_{i}\left(k_{\text {som }}^{i} f^{i}(\mathrm{~T}) C_{S O M}^{i}\right) f(\mathrm{~W}) F(\mathrm{~N})
\end{aligned}
$$

where $k_{\mathrm{tr}}$ is the transfer rate of decomposed LIT to SOM (we suppose the transformation only occurs between these pools: $\mathrm{LIT}_{\mathrm{v}}$ to $\mathrm{SOM}_{\mathrm{v}}, \mathrm{LIT}_{\mathrm{m}}$ to $\mathrm{SOM}_{\mathrm{m}}$, and $\mathrm{LIT}_{\mathrm{r}}$ to $\mathrm{SOM}_{\mathrm{r}}$ ); $k_{\text {gppdoc }}$ is the fraction of GPP conversion into soil DOC; $K_{\text {trprd }}$ is the returned rate of decomposed (or consumed) PRD to SOM pools as manure; $k_{\mathrm{rh}}$ is the fraction of decomposed SOM that is converted to $\mathrm{CO}_{2}$ through heterotrophic respiration; 
$\mathrm{DOC}_{\text {loss,microb }}$ and $\mathrm{DOC}_{\text {loss,methane }}$ are DOC consumed for the growth of microbe and production of methane; $f(T), f(W)$, and $f(N)$ are scalar of decomposition rate controlled by temperature, soil moisture, and available of nitrogen, respectively, which have same meanings with equations in LIT decomposition; $k_{\text {luccsomcvt }}$ is coefficient for quick carbon loss from SOM due to land use conversion; $\mathrm{C}_{\text {SOM }}^{i}$ is the carbon content of $\mathrm{SOM}_{i}$. The decomposition of DOC is assumed as half rate of $\mathrm{SOM}_{\mathrm{v}}$ and will directly be converted into atmospheric $\mathrm{CO}_{2}$. As to $\mathrm{SOM}_{\mathrm{v}}$ and $\mathrm{SOM}_{\mathrm{m}}$, they are either converted into DOC and more stable SOM pools (i.e. $\mathrm{SOM}_{\mathrm{v}}$ to $\mathrm{SOM}_{\mathrm{m}}, \mathrm{SOM}_{\mathrm{m}}$ to $\mathrm{SOM}_{\mathrm{r}}$ ), or released as atmospheric $\mathrm{CO}_{2}$. The decomposition of $\mathrm{SOM}_{\mathrm{r}}$, however, just produces DOC and $\mathrm{CO}_{2}$.

\section{Input data}

To run the DLEM-Ag module, four types of datasets are needed (including baseline and transient data) (Table 1, appendix): (1) dynamic crop distribution maps, (2) topography and soil properties (e.g. elevation, slope, and aspect; $\mathrm{pH}$, bulk density, soil texture represented as the percentage content of clay, sand, and silt), (3) natural environmental factors including climate (e.g. maximum, minimum, and average temperature; precipitation; and relative humidity) and atmospheric chemistries (e.g. $\mathrm{CO}_{2}, \mathrm{O}_{3}$, and nitrogen deposition), and (4) agronomic practices (fertilization, irrigation, harvest, rotation, and residue treatment).

Table 1 Simulation experiment design

\begin{tabular}{rllllll}
\hline & Simulations & Climate & $\mathrm{CO}_{2}$ & $\mathrm{O}_{3}$ & NDEP & LCLUC \\
\hline & Equilibrium & $\mathrm{C}$ & $\mathrm{C}$ & $\mathrm{C}$ & $\mathrm{C}$ & $\mathrm{C}$ \\
1 & All-Com & $\mathrm{H}$ & $\mathrm{H}$ & $\mathrm{H}$ & $\mathrm{H}$ & $\mathrm{H}$ \\
2 & No-Climate & $\mathrm{C}$ & $\mathrm{H}$ & $\mathrm{H}$ & $\mathrm{H}$ & $\mathrm{H}$ \\
3 & $\mathrm{No-CO}_{2}$ & $\mathrm{H}$ & $\mathrm{C}$ & $\mathrm{H}$ & $\mathrm{H}$ & $\mathrm{H}$ \\
4 & $\mathrm{No-O}_{3}$ & $\mathrm{H}$ & $\mathrm{H}$ & $\mathrm{C}$ & $\mathrm{H}$ & $\mathrm{H}$ \\
5 & No-NDEP & $\mathrm{H}$ & $\mathrm{H}$ & $\mathrm{H}$ & $\mathrm{C}$ & $\mathrm{H}$ \\
6 & No-LCLUC & $\mathrm{H}$ & $\mathrm{H}$ & $\mathrm{H}$ & $\mathrm{H}$ & $\mathrm{C}$ \\
7 & No-Nfer & $\mathrm{H}$ & $\mathrm{H}$ & $\mathrm{H}$ & $\mathrm{H}$ & $\mathrm{C}$ \\
8 & $\mathrm{Climate} \mathrm{only}$ & $\mathrm{H}$ & $\mathrm{C}$ & $\mathrm{C}$ & $\mathrm{C}$ & $\mathrm{C}$ \\
9 & $\mathrm{CO}_{2}$ only & $\mathrm{C}$ & $\mathrm{H}$ & $\mathrm{C}$ & $\mathrm{C}$ & $\mathrm{C}$ \\
10 & $\mathrm{O}_{3}$ only & $\mathrm{C}$ & $\mathrm{C}$ & $\mathrm{H}$ & $\mathrm{C}$ & $\mathrm{C}$ \\
11 & NDEP only & $\mathrm{C}$ & $\mathrm{C}$ & $\mathrm{C}$ & $\mathrm{H}$ & $\mathrm{C}$ \\
12 & LCLUC only & $\mathrm{C}$ & $\mathrm{C}$ & $\mathrm{C}$ & $\mathrm{C}$ & $\mathrm{H}$ \\
13 & LMonly & $\mathrm{C}$ & $\mathrm{C}$ & $\mathrm{C}$ & $\mathrm{C}$ & $\mathrm{H}$ \\
14 & LC only & $\mathrm{C}$ & $\mathrm{C}$ & $\mathrm{C}$ & $\mathrm{C}$ & $\mathrm{H}$ \\
\hline
\end{tabular}

$\mathrm{H}$ means historical and $\mathrm{C}$ means constant. All-Com including historical changes in climate, carbon dioxide $\left(\mathrm{CO}_{2}\right)$, ozone $\left(\mathrm{O}_{3}\right)$, nitrogen deposition (NDEP), Landcover, and landuse (LCLUC); No-Climate, No- $\mathrm{CO}_{2}, \mathrm{No}-\mathrm{O}_{3}, \mathrm{No}-\mathrm{NDEP}, \mathrm{No}-$ LCLUC, No-Nfer are All-Com without changes in climate (precipitation, temperature), $\mathrm{CO}_{2}, \mathrm{O}_{3}, \mathrm{NDEP}$, LCLUC (N fertilization, irrigation, land conversion etc.), respectively; singlefactor experiments consider changes in climate (Climate only), $\mathrm{CO}_{2}\left(\mathrm{CO}_{2}\right.$ only), $\mathrm{O}_{3}\left(\mathrm{O}_{3}\right.$ only), $\mathrm{N}$ deposition (NDEP only), LCLUC (LCLUC only), land management (nitrogen fertilizer\& irrigation, LM only), and land cover (LC only) individually.
We developed the historical time series data of crop distribution, daily climate, annual nitrogen deposition, and fertilizer application from 1980 to 2005. On the basis of observational and survey data at site, county, and provincial levels in China (see details in Ren et al., 2007; Liu \& Tian, 2010; Lu et al., 2012). Soil data were derived from the $1: 1$ million scale soil maps based on the second national soil survey of China (Shi et al., 2004; Tian et al., 2010a). Elevation, slope, and aspect maps were derived from $1-\mathrm{km}$ resolution digital elevation dataset of China (http://www.wdc.cn/wdcdrre). Historical $\mathrm{CO}_{2}$ concentration dataset was from the standard Intergovernmental Panel on Climate Change (IPCC). The AOT40 dataset (an index of the accumulated hourly $\mathrm{O}_{3}$ concentrations above a threshold of $40 \mathrm{ppb}-\mathrm{hr}$ ) was derived from the global historical AOT40 datasets constructed by Felzer et al. (2005) and was described in detail by Ren et al. (2007). All datasets have a spatial resolution of $10 \times 10 \mathrm{~km}$. The Climate and AOT40 datasets are in a daily time step whereas the $\mathrm{CO}_{2}$ and land-use datasets are at a yearly time step. The details of the datasets were described in our previous work (Ren et al., 2011a; Tian et al., 2011a,b).

Rapid environmental changes have occurred across China's croplands over the study period with large temporal-spatial variations (Fig. 2). In general, historical climate datasets have shown substantial interannual and decadal variations in annual precipitation and mean annual temperature, with an observable climate warming trend in some regions since the 1980s (Fig. 2a and b). The simulated $\mathrm{O}_{3}$ index AOT40 showed significant increase in $\mathrm{O}_{3}$ pollution, with a sharply accelerated trend since the early 1990s (Fig. 2c). Both the nitrogen fertilizer application and the nitrogen deposition obviously increased (Fig. 2e and f). At national level, the cropland area decreased slightly by 4.6 Mha during 1980-1990 while increased by 3.0 Mha during 1990-2000 due to large crop expansion in Northeastern (NE) region (Fig. 2d). In the last 5 years of this study, cropland declined again, by 6.8 Mha. Atmospheric $\mathrm{CO}_{2}$ concentration steadily increased. Among the five regions, Southeastern region (SE), with the largest cropland area, high precipitation and temperature, experienced low $\mathrm{O}_{3}$ pollution and high nitrogen inputs, whereas Northwestern region (NW), with the smallest cropland area, low precipitation and temperature, experienced high $\mathrm{O}_{3}$ pollution and low nitrogen inputs. Those changes were consistent to field observations and other studies (e.g. Felzer et al., 2005; Liu et al., 2005; Wang et al., 2007; Lu et al., 2009).

\section{Model parameterization}

The DLEM-Ag had been calibrated against field data from the Chinese Ecological Research Network and AmeriFlux network (http://www.fluxnet.ornl.gov/fluxnet/index.cfm). Crop generic parameters, such as phenological development, were based on agroecosystem experimental stations' observations and remote sensing data. The details on these agricultural sites have been documented in our recent study (Ren et al., 2011a). The model parameters pertinent to the NPP and to the SOC processes were mostly derived from field observations with extrapolated inputs based on other auxiliary data. Due to the limitation of data availability and the difficulty in collecting 

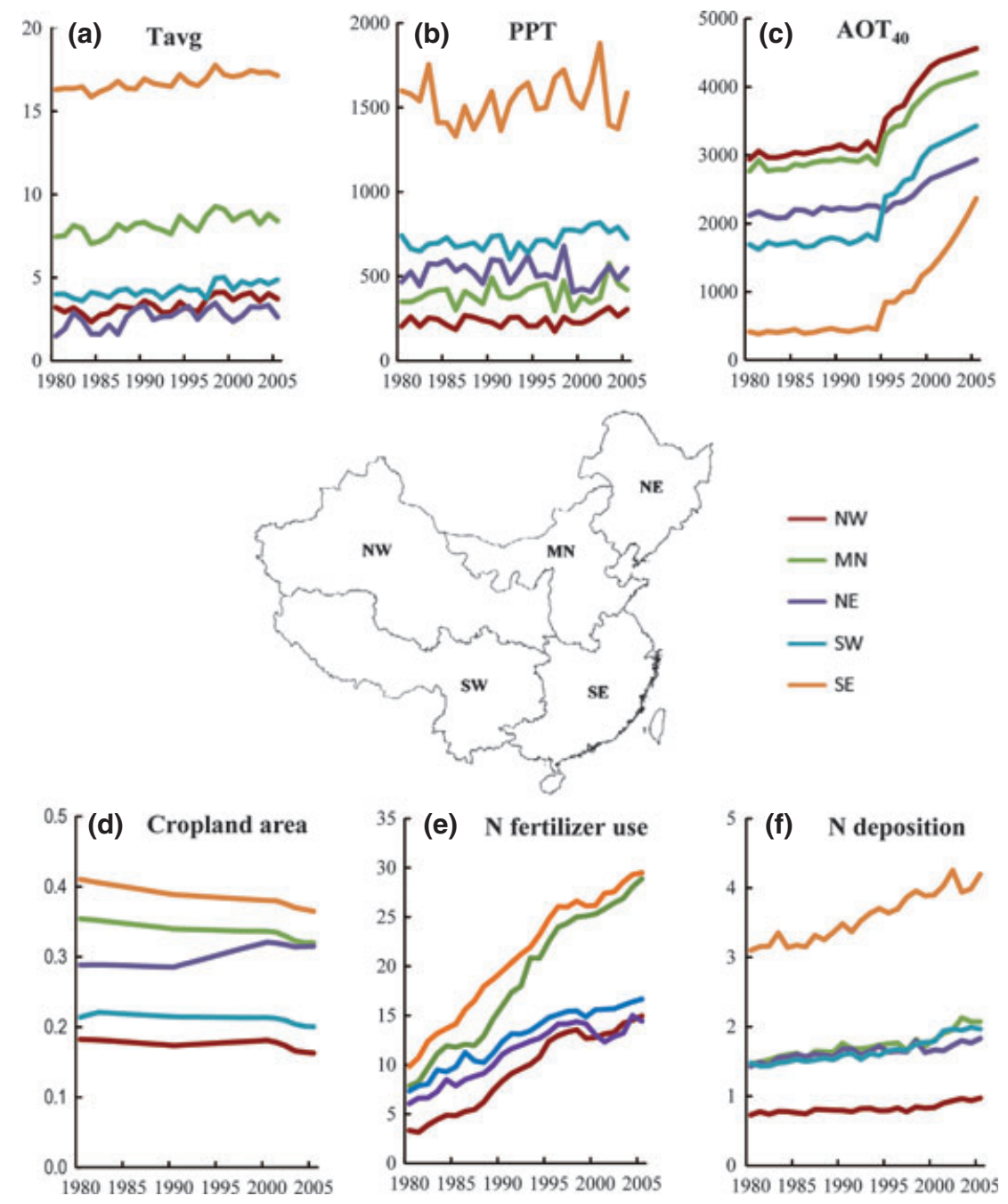

Fig. 2 Changes in multiple environmental stresses including annual mean average temperature Tavg $\left({ }^{\circ} \mathrm{C}\right)($ a) precipitation PPT (mm) (b) ozone index AOT40 (PPb-hr) (c) total cropland area $\left(10^{8} \mathrm{ha}\right)(\mathrm{d})$ nitrogen fertilizer application $\left(\mathrm{g} \mathrm{N} \mathrm{m}^{-2}\right)$ (e) and nitrogen deposition $\left(\mathrm{g} \mathrm{N} \mathrm{m}^{-2}\right.$ ) (f) in five regions of China's croplands during the period 1980-2005.

NPP and SOC site data for all crop types, in this study, some observational SOC data were collected from the literature and most NPP values were calculated using the crop yield method described by Huang et al. (2007). In addition, optimized parameters relating to the model's behavior for addressing the $\mathrm{C}$ fluxes and pools responses to environmental changes, including climate variability/change, increasing nitrogen inputs, elevated $\mathrm{CO}_{2}$ and $\mathrm{O}_{3}$ pollution, and land conversion, have been evaluated and applied in previous work (Tian et al., 2011a,b; Ren et al., 2011a).

\section{Model performance evaluation}

The simulation results for the carbon fluxes and pools in China's agricultural ecosystem were validated at site level in our previous studies (Tian et al., 2011a,b; Ren et al., 2011a). Here, to examine the model performance at regional level, the spatial and temporal patterns of crop NPP and SOC at provincial and national levels, we further compared simulated NPP and
SOC with survey, meta-analysis, and remote sensing (RS)based data (Table 2; Figs 3 and 4).

The temporal pattern of crop NPP at national level during the study period was evaluated against the remote sensing dataset (Fig. 3). We particularly compared our simulated crop NPP with results from the Global Production Efficiency Model (GLO-PEM), which has a spatial 8-km resolution and runs at a 10-day time step. GLO-PEM was driven almost entirely by satellite-derived variables, including both the Normalized Difference Vegetation index (NDVI) and meteorological variables (Prince \& Goward, 1995; Goetz et al., 2000). We overlaid the GLO-PEM NPP images with the yearly cropland distribution data that we had developed and extracted previously. Similarly, we obtained the Moderate Resolution Imaging Spectroradiometer (MODIS) MOD 17 NPP for 2002 to 2005 (Zhao et al., 2005) and the Advanced Very High Resolution Radiometer (AVHRR) NPP for 1981 to 2000 (Nemani et al., 2003; Running et al., 2004). The results showed that the DLEMsimulated NPP had the similar temporal pattern with relative 
Table 2 Comparisons of results estimated by modeling, survey, meta-analysis, and satellite-based methods at national and cropping system levels: variations and responses of soil carbon storage and net primary productivity to multiple environmental factors

\begin{tabular}{|c|c|c|c|c|c|c|}
\hline \multirow[b]{2}{*}{ Factors } & & \multicolumn{4}{|l|}{ Other studies } & \multirow{2}{*}{$\begin{array}{l}\text { This study } \\
\text { Results }\end{array}$} \\
\hline & & Time period & Method & Reference & Results & \\
\hline \multirow[t]{10}{*}{ All-Com } & & \multirow[t]{3}{*}{$1980-2000$} & \multirow[t]{2}{*}{ Inventory } & \multirow[t]{2}{*}{ Huang \& Sun, 2006} & \multicolumn{2}{|c|}{ 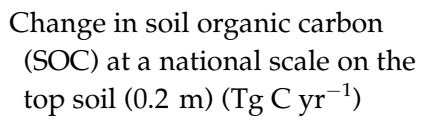 } \\
\hline & & & & & $15.6-20$ & $8-24$ \\
\hline & & & Meta-analysis & Sun et al., 2010 & \multicolumn{2}{|l|}{$17-28$} \\
\hline & & 1982-2005 & Meta-analysis & Wu and Cai, 2007 & $8-64$ & $10-23$ \\
\hline & & 1980-2000 & $\begin{array}{l}\text { Process-based } \\
\text { model }\end{array}$ & Zhang et al., 2007 & \multicolumn{2}{|c|}{$\begin{array}{l}\text { Change in SOC in rice paddy } \\
\text { field on the top soil }(0.2 \mathrm{~m}) \\
\left(\mathrm{Tg}_{\mathrm{Cyr}}^{-1}\right)\end{array}$} \\
\hline & & & & & $3.8-10.5$ & 5.3 \\
\hline & & 1980-1999 & Inventory & Huang et al., 2007 & \multicolumn{2}{|c|}{ 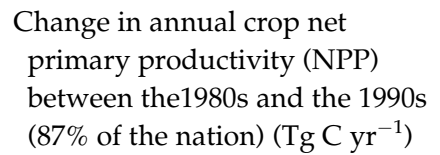 } \\
\hline & & & & & $83-145$ & 89 \\
\hline & & 1990-2000 & $\begin{array}{l}\text { Satellite-based } \\
\text { model }\end{array}$ & Yan et al., 2009 & \multicolumn{2}{|c|}{$\begin{array}{l}\text { Change in annual crop NPP in } \\
\text { the 1990s across China's } \\
\text { cropland ( }{\left.\mathrm{Tg} \mathrm{C} \mathrm{yr}^{-1}\right)}^{-1}\end{array}$} \\
\hline & & & & & 150 & 51-137 \\
\hline \multirow[t]{5}{*}{ Ozone } & & 1981-2000 & $\begin{array}{l}\text { Process-based } \\
\text { model }\end{array}$ & Ren et al., 2007 & \multicolumn{2}{|c|}{ 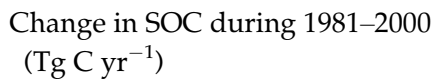 } \\
\hline & & & & & -3.3 & -3.9 \\
\hline & & 1990 & Empirical & Aunan et al., 2000 & \multicolumn{2}{|c|}{ Crop yield change in $1990(\%)$} \\
\hline & & & models & & Spring wheat 9.1 & $3.6-8.4$ \\
\hline & & & & & Winter wheat 1.7 & $1.3-6.1$ \\
\hline \multirow[t]{7}{*}{ LCLUC } & Fertilizer & Baseline in 1998 & Modeled & Tang et al., 2006 & \multicolumn{2}{|c|}{ 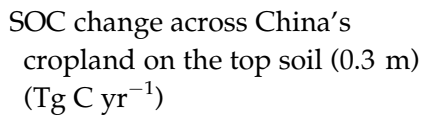 } \\
\hline & & & & & 11 & 19 \\
\hline & & Baseline in 2005 & Meta-analysis & Lu et al., 2009 & $6-12$ & 16.4 \\
\hline & & 1980-2005 & Meta-analysis & Liu \& Zhang, 2011 & \multicolumn{2}{|c|}{$\begin{array}{l}\text { SOC change across China's } \\
\text { cropland on the top soil }(0.2 \mathrm{~m}) \\
\left(\mathrm{TgC}_{\mathrm{yr}}^{-1}\right)\end{array}$} \\
\hline & & & & & $7.5-10$ & 15 \\
\hline & $\begin{array}{l}\text { Land use } \\
\text { change }\end{array}$ & $1990-2000$ & $\begin{array}{l}\text { Satellite-based } \\
\text { model }\end{array}$ & Yan et al., 2009 & \multicolumn{2}{|c|}{$\begin{array}{l}\text { Change in annual crop NPP } \\
\text { across China's cropland } \\
\left(\mathrm{Tg}_{\mathrm{yr}}^{-1}\right)\end{array}$} \\
\hline & & & & & 6.96 & $2.4-6.4$ \\
\hline
\end{tabular}

higher values than those estimated by GLO-PEM and by MODIS MOD17. A possible explanation of the underestimation by GLO-PEM might be due to the fact that nitrogen is not factored into the model. MODIS MOD 17 results might be influenced by the LAI, which tends to be underestimated by MODIS MOD 17 (Zhang et al., 2008). Similarly, the uncertainties of input data and parameters adopted in DLEM could lead to higher simulated NPP, for example, we did not include vegetation crop types in this study and assumed that all croplands were dominant by food crop types.

We examined the spatial pattern of crop NPP and SOC changes by comparing the simulated results with survey reports and meta-analysis-based database at the provincial level (Fig. 4). Similarly, we compared our results with estimates derived from survey, meta-analysis, process-based, and remote sensing-based models at national level (Table 2). All of these showed a similar spatial pattern: during 1980-2000, both crop NPP and SOC increased at national level, either simulated by DLEM-Ag module or estimated by other approaches (survey, meta-analysis, and models); while decreased in some provinces estimated by DLEM model and survey/meta-analysis (Fig. 4a and b). For SOC changes in the upper 20 centimeters of soil at national level, the DLEM-Ag estimated an increase rate of 8-24 $\mathrm{Tg} \mathrm{C} \mathrm{yr}^{-1}$, which was close to the range of $12-21 \mathrm{Tg} \mathrm{C} \mathrm{yr}^{-1}$ reported by the Huang \& Sun (2006) using a survey method and by Sun et al. (2010) using a meta-analysis 


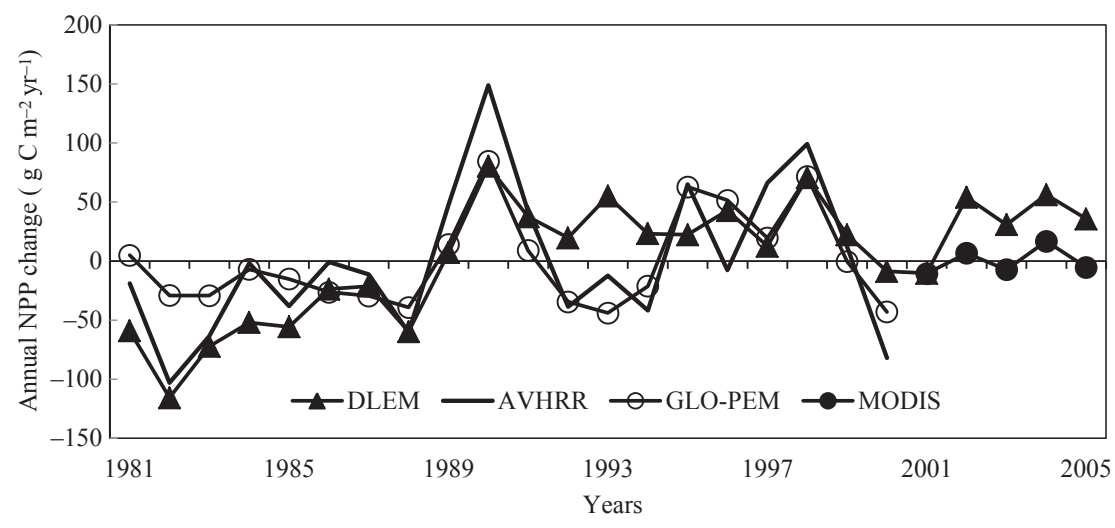

Fig. 3 Changes in annual net primary production (NPP) (relative to the average for 1981-2005) of China's croplands estimated by DLEM-Ag module, GLO-PEM model (Prince \& Goward, 1995; Goetz et al., 2000; http://glcf.umiacs.umd.edu/data/glopem/), AVHRR (Nemani et al., 2003), and MODIS (Zhao et al., 2005) database during 1981-2005.
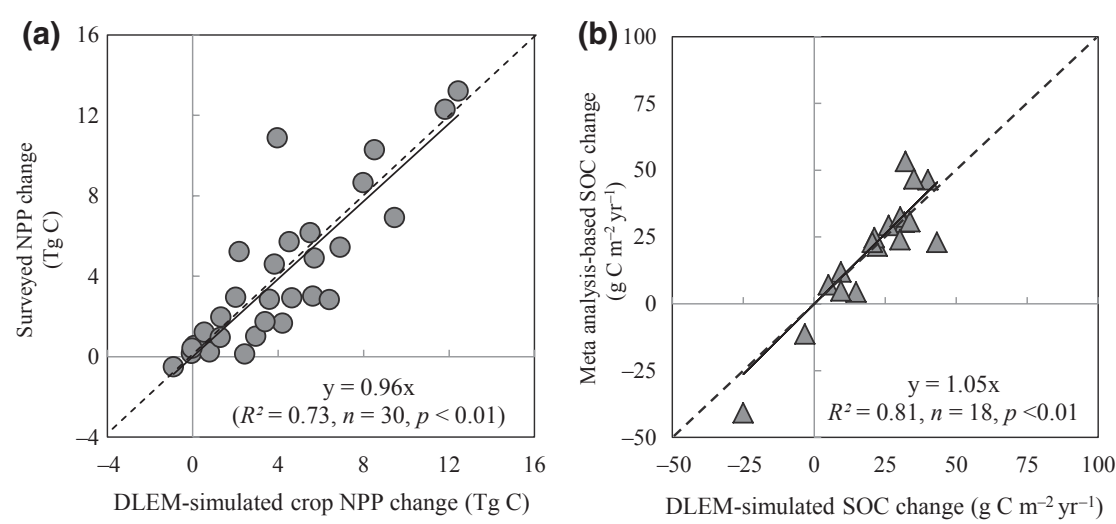

Fig. 4 (a) Comparison of survey based and DLEM-simulated changes in annual net primary productivity (NPP) between the 1990s and the 1980s; (b) comparison of meta-analysis based and DLEM-simulated changes in soil organic carbon storage (SOC) between 1980 and 2000 across China's croplands at provincial level. Note: survey based NPP is from Huang et al. (2007) including 30 provinces; metaanalysis based SOC is recalculated from Sun et al. (2010) including 18 provinces.

approach. The DLEM-Ag estimated the increase in the annual NPP for the 1980s and the 1990s as $89 \mathrm{Tg} \mathrm{C} \mathrm{yr}^{-1}$, which fell in

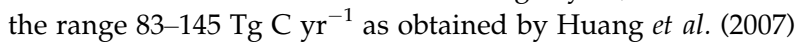
survey. When comparing the NPP for the 1990s, the DELM-

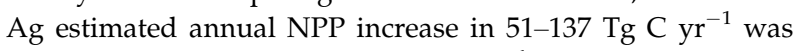
lower than the estimate of $150 \mathrm{Tg} \mathrm{C} \mathrm{yr}^{-1}$ provided by a satellite-based model (Yan et al., 2009).

\section{Experimental design and model implementation}

We designed fourteen experiments to analyze the relative contribution of each environmental factor to crop NPP and SOC in China's croplands (Table 1). In the first seven simulations, we attempted to capture both direct effects of an environmental factor and its interactive effects with other environmental factors. We conducted five single-factor simulations to test the effect of each factor and this was carried out allowing a specific environmental factor to change over time with keeping other environmental factors constant. Additional two simulations were designed to further identify the relative contributions of land conversion and land management practices.
The model was run at a daily time step for simulating crop development and growth. The model simulation began with an equilibration run, which was defined as the year-to-year changes in carbon, nitrogen, and water pools in each grid would be less than $0.1 \mathrm{~g} \mathrm{C} \mathrm{m}^{-2}, 0.1 \mathrm{~mm}$ $\mathrm{H}_{2} \mathrm{O}$, and $0.1 \mathrm{~g} \mathrm{~N} \mathrm{~m}^{-2}$ with a spin-up time up to 20000 years. A 100-year spin-up was applied if climate change was included in the simulation experiments and a 1000-year spin-up was used if no irrigation would be considered in the simulation experiments. Finally, the model was fed by the time series of input dataset in the transient mode.

\section{Results}

\section{Spatial and temporal variations in NPP and soil carbon storage}

NPP. Our estimates indicated that total NPP at the

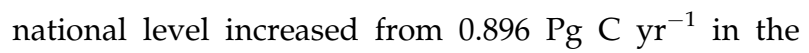


1980s to $0.978 \mathrm{Pg} \mathrm{C} \mathrm{yr}^{-1}$ in the 1990s and leveled off or even had a slight decrease in the years that followed (2001-2005) (Table 3). A steady increase in the average NPP was observed from $613.9 \mathrm{~g} \mathrm{C} \mathrm{m}^{-2} \mathrm{yr}^{-1}$ in the 1980 s to $693.0 \mathrm{~g} \mathrm{C} \mathrm{m}^{-2} \mathrm{yr}^{-1}$ in 2001-2005. Apparently, the decrease in crop area since 2001 accounted for the reduction in total NPP, while the extensive use of nitrogen fertilizer contributed to the largest part of the average NPP increase.

Regional analysis showed large spatial and temporal variations in the NPP. When investigating the average NPP over the study period, the higher NPP occurred in Southeast (SE) with $0.32 \mathrm{Pg} \mathrm{C} \mathrm{yr}^{-1}$ (35.4\% of the total NPP) and Mid-north (MN) with $0.23 \mathrm{Pg} \mathrm{C} \mathrm{yr}^{-1}(25.7 \%)$; the lower NPP values were found in Northwest (NW),

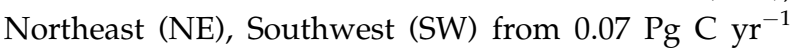

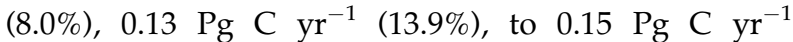
$(17.1 \%)$, respectively (Table 3$)$. However, the spatial distribution of changes in NPP (difference between 2005 and 1980) showed that NPP decreased in some areas in $\mathrm{MN}$ which experienced frequent drought and high air pollution (Fig. 5).

Soil carbon storage. Soil carbon storage continued to increase during 1980-2005, ranging from 5.98 Pg C

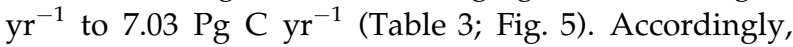
the mean carbon storage in agricultural ecosystems increased from $4194.2 \mathrm{~g} \mathrm{C} \mathrm{m}^{-2} \mathrm{yr}^{-1}$ in the $1980 \mathrm{~s}$ to $5068.8 \mathrm{~g} \mathrm{C} \mathrm{m}^{-2} \mathrm{yr}^{-1}$ in the period of 2000-2005. Unlike natural ecosystems, carbon sequestration in agricultural ecosystems mainly occurs in the soil carbon pool. Increased vegetation carbon can also provide more lit-

Table 3 Decadal mean carbon flux and carbon pool at regional and national levels

\begin{tabular}{|c|c|c|c|c|c|c|c|}
\hline \multirow[b]{2}{*}{ Time period } & \multicolumn{5}{|c|}{ Total $\left(\operatorname{Pg~C~yr}^{-1}\right)$} & \multicolumn{2}{|c|}{$\begin{array}{l}\text { Mean } \\
\left(\mathrm{g} \mathrm{C} \mathrm{m}^{-2} \mathrm{yr}^{-1}\right)\end{array}$} \\
\hline & NW & $\mathrm{MN}$ & $\mathrm{NE}$ & SW & SE & Nation & Nation \\
\hline \multicolumn{8}{|c|}{ Net primary productivity (NPP) } \\
\hline $1980 \mathrm{~s}$ & 0.064 & 0.220 & 0.112 & 0.147 & 0.307 & 0.876 & 613.9 \\
\hline 1990s & 0.077 & 0.242 & 0.133 & 0.164 & 0.335 & 0.978 & 689.5 \\
\hline 2000-2005 & 0.079 & 0.242 & 0.140 & 0.156 & 0.319 & 0.961 & 693.0 \\
\hline Average & $0.07(8.0 \%)$ & $0.23(25.7 \%)$ & $0.13(13.9 \%)$ & $0.15(17.1 \%)$ & $0.32(35.4 \%)$ & & \\
\hline (1990s-1980s) \% & 20.4 & 10.0 & 17.9 & 11.4 & 9.1 & & \\
\hline \multicolumn{8}{|c|}{ Soil organic carbon (SOC) } \\
\hline 1980s & 0.68 & 1.06 & 2.08 & 0.85 & 1.33 & 5.98 & 4194.2 \\
\hline 1990s & 0.72 & 1.18 & 2.41 & 0.94 & 1.47 & 6.73 & 4743.5 \\
\hline 2000-2005 & 0.69 & 1.22 & 2.61 & 0.97 & 1.54 & 7.03 & 5068.8 \\
\hline Average & $0.70(10.9 \%)$ & $1.13(17.7 \%)$ & $2.29(35.9 \%)$ & $0.90(14.1 \%)$ & $1.42(22.2 \%)$ & & \\
\hline$(1990 \mathrm{~s}-1980 \mathrm{~s}) \%$ & 7.1 & 11.7 & 15.8 & 11.4 & 11.0 & & \\
\hline
\end{tabular}

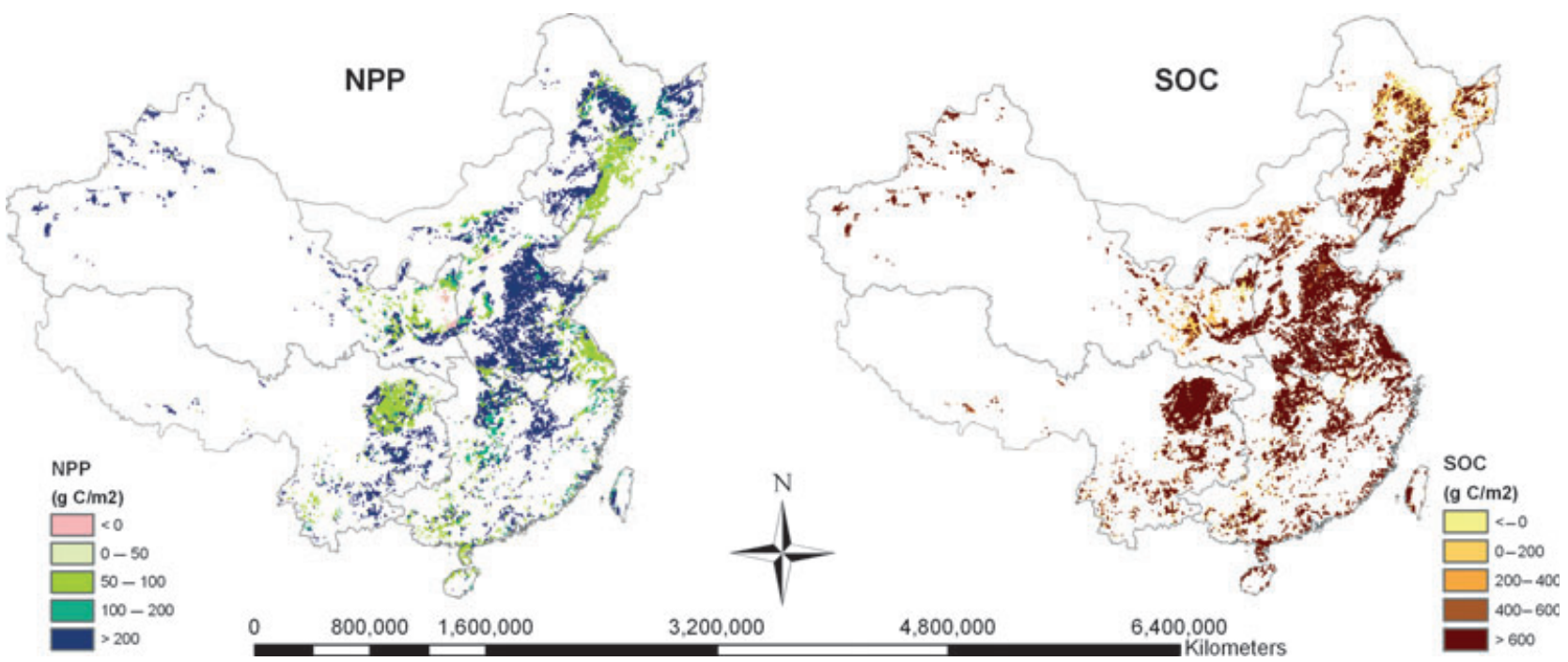

Fig. 5 Changes in net primary productivity (NPP) and soil organic carbon (SOC) ( $\mathrm{g} \mathrm{C} \mathrm{m}^{-2}$ ) between 1980 and 2005. 
ter fall as input into the soil carbon pool, which would result in enhanced soil carbon storage.

Soil carbon storage in the NE was highest among the five regions, accounting for $35.9 \%$ of the total soil carbon storage. SE and $\mathrm{MN}$ accounted for $22.2 \%$ and $17.7 \%$ of total soil carbon storage, respectively. During the past 26 years, soil carbon storage continued to increase in four of the five regions with value changes ranging from 1.06 to $1.22 \mathrm{Pg} \mathrm{C}$ for the $\mathrm{MN}$, from 2.08 to 2.61Pg $\mathrm{C}$ for the NE, from $0.852-0.97 \mathrm{Pg} C$ for the $\mathrm{SW}$, and from 1.33 to $1.54 \mathrm{Pg} \mathrm{C}$ for the SE, while the NW was the only region to experience a decrease in the total soil carbon storage from the 1990s onward (Table 3). Further analysis (Fig. 5) showed that the SOC increased in most areas except some NE places where a higher rate of land conversion from wetlands to croplands occurred.

\section{Environmental controls on NPP and soil carbon storage}

The simulated total crop NPP under multiple environmental changes significantly increased from 1980 to
2005 , however, the relative contribution of the five environmental factors investigated in this study varied largely (Fig. 6a). LCLUC accounted for $87.1 \%$ of the total NPP increase over the 26 year period. $\mathrm{CO}_{2}$ fertilization was the second most important factor that contributed an additional $18.0 \%$ of the total NPP increase, whereas nitrogen deposition (NDEP) accounted for 7.5\%. Tropospheric $\mathrm{O}_{3}$ pollution and climate variability/change decreased NPP by $\sim 10.7 \%$ and $\sim 2.0 \%$, respectively. The change in the annual NPP was related to all these environmental factors. LCLUC, $\mathrm{CO}_{2}$, and NDEP had positive effects on NPP increase whereas $\mathrm{O}_{3}$ pollution had an increasingly greater negative impact on the NPP over the study period. Climate variability/change caused some NPP variation, which was due largely to changes in annual precipitation.

Among the combined effects of the multiple stresses on the total SOC, LCLUC played a key role by contributing $95.8 \%$ to the total increase in SOC, followed by $\mathrm{CO}_{2}(22.6 .4 \%)$ and by NDEP (0.9\%) (Fig. 6b). The tropospheric $\mathrm{O}_{3}$ pollution and climate variability/change decreased soil carbon storage by $\sim 12.6 \%$ and $\sim 6.7 \%$,
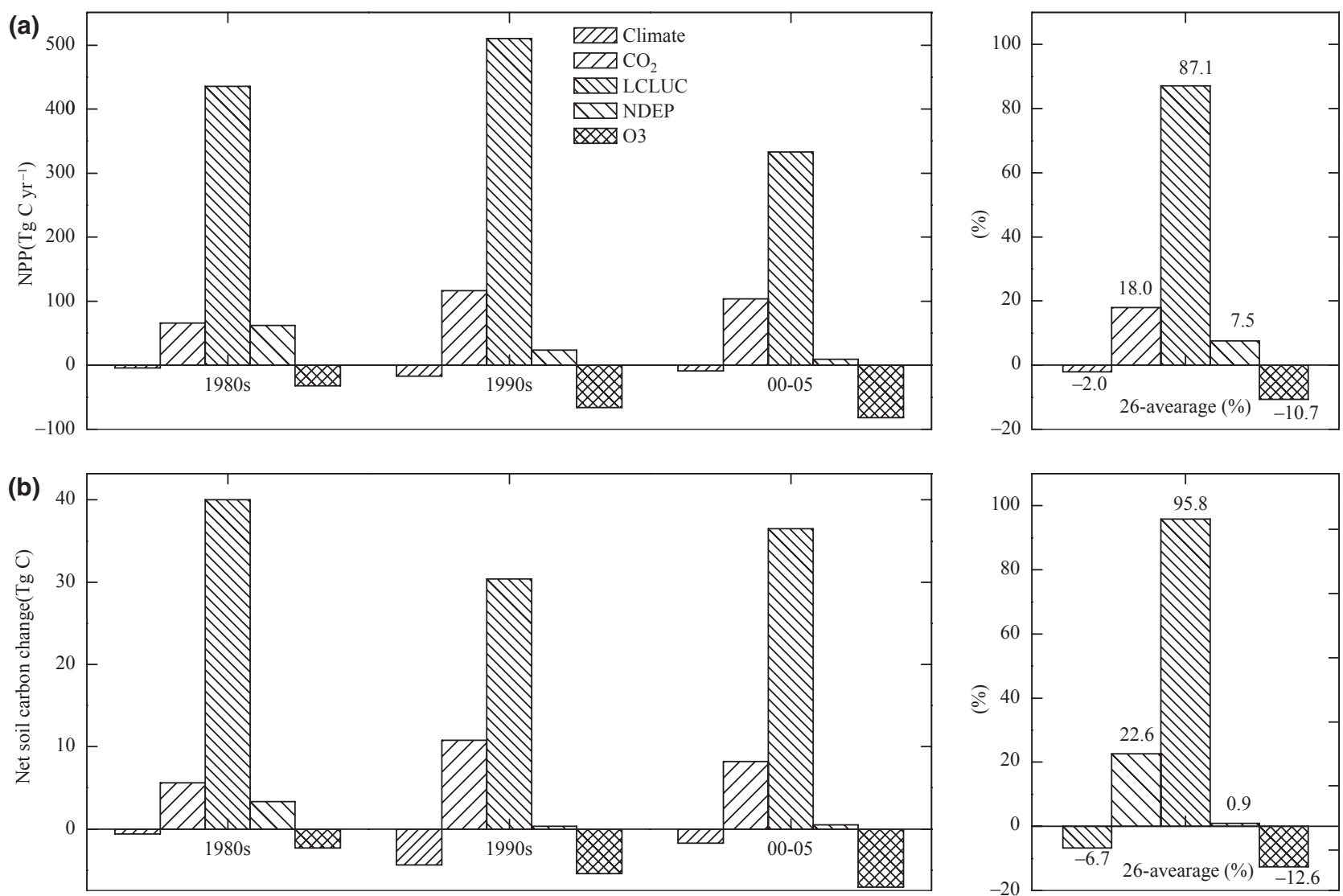

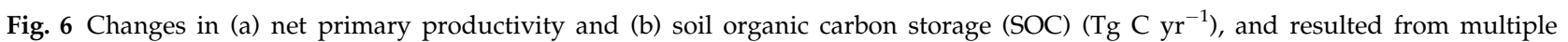
environmental factors including climate, $\mathrm{CO}_{2}, \mathrm{O}_{3}$, Nitrogen deposition (NDEP), Land-cover/land-use change (LCLUC) in the 1980s, the 1990s, recent 6 years between 2000 and 2005; and the relative contribution rate (\%) on average during the study period $1980-2005$. 
respectively. The decadal mean contributions of the multiple stresses indicated that $\mathrm{CO}_{2}$ fertilization and LCLUC had obviously positive effects on the annual total SOC increase while $\mathrm{O}_{3}$ pollution had an increasing negative impact over the study period. Relatively speaking, NDEP had a very small positive contribution for increasing the soil carbon storage.

To further explore the effects of LCLUC, we conducted two additional simulations, land conversion only (LC only) and land management only (nitrogen fertilizer and irrigation, LM). In general, relative to the overall changes in NPP and SOC induced by LCLUC, land management increased crop NPP and SOC by over $100 \%$ while land conversion reduced crop NPP and SOC by approximately $2 \%$ and $24 \%$, respectively between 1980 and 2005. The decadal means showed that during the study period land management continuously contributed to large increases in crop productivity and soil carbon storage. Land conversion enhanced crop NPP and SOC in the $1990 \mathrm{~s}$ as cropland area increased while resulted in carbon loss in the 1980s and recent 6 years (2000-2005) due to cropland decrease. Similar results were reported in other studies (Liu et al., 2005; Tang et al., 2006; Lu et al., 2009).

\section{Discussion}

\section{Estimation of NPP and SOC in China's croplands}

Because of the tremendous influences of human activities, carbon pools in agricultural ecosystems are the most active of global carbon pools. IPCC reported that carbon sequestration in global agricultural soils could reach $40-80 \mathrm{Pg} \mathrm{C}$ in the coming 50-100 years (Paustian et al., 1998). In this study, the simulated SOC in China's croplands was $7.03 \mathrm{Pg} \mathrm{C}$ for the recent years (2000 -2005), which would account for $8.8-17.6 \%$ of the global carbon sequestration in agricultural soils. Furthermore, the simulated continuous increase in SOC since 1980 indicates that China's croplands have large potential for soil carbon sequestration. The estimated NPP in China's croplands has also increased since 1980 , indicating that increased vegetation carbon storage thus would enhance the soil carbon storage (Table 2).

\section{Contributions of multiple environmental changes to NPP} and SOC

Land cover and land use change. The LCLUC factors investigated in this study included the influences of land conversion and land management (e.g. irrigation, fertilizer application). We found that LCLUC was the
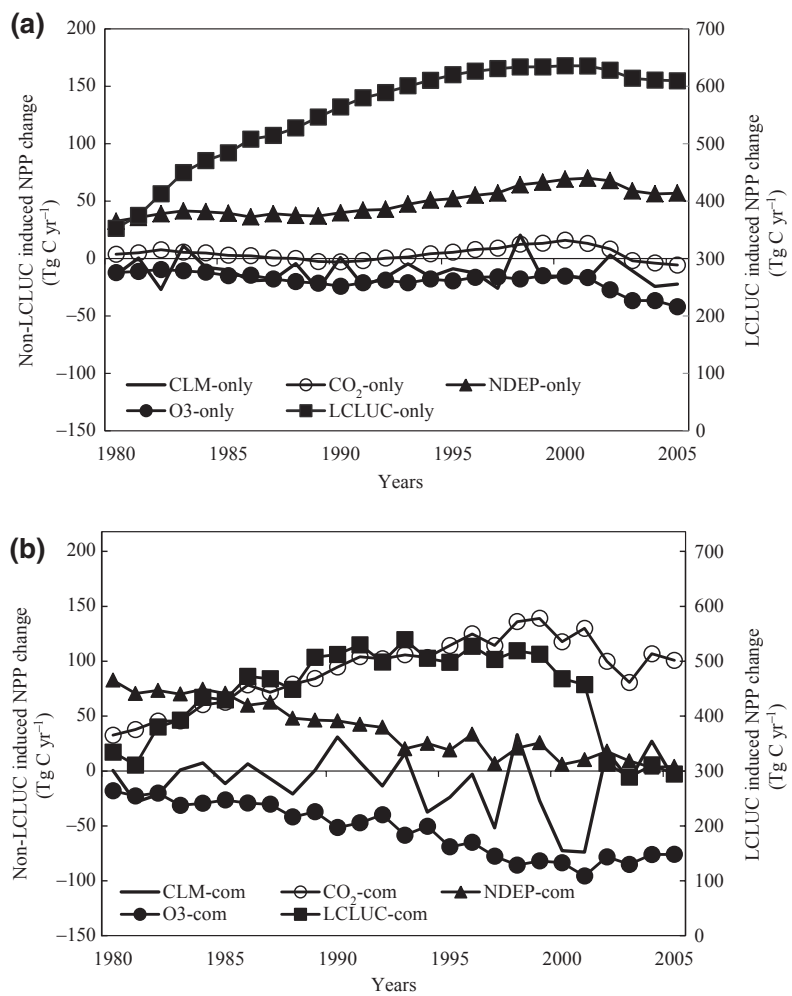

Fig. 7 Annual changes in net primary productivity (NPP) (Tg C $\mathrm{yr}^{-1}$ ) derived from single-factor experiments (a) and combination experiments (b). Note: CLM-only, $\mathrm{CO}_{2}$-only, LCLUC-only, NDEP-only and $\mathrm{O}_{3}$-only mean the single effect of climate, $\mathrm{CO}_{2}$, land-cover/land-use change (LCLUC), nitrogen deposition and $\mathrm{O}_{3}$, respectively; -com stands for the combination effects of a single factor plus the interactive effects with other factors.

dominant factor controlling the temporal and spatial variations of NPP and SOC in China's croplands during 1980-2005, accounting for more than $80 \%$ of the total changes in NPP and over $90 \%$ of the total soil carbon accumulations. Similar to other studies, we found that land converted from natural vegetation to cropland could lead to an increase in the NPP and SOC levels (Davidson \& Ackerman, 1993; Guo \& Gifford, 2002; Murty et al., 2002) and could also result in a reduction in total NPP and SOC when cropland area was decreased. Furthermore, we analyzed the influences of nitrogen fertilizer on the annual crop NPP and soil carbon storage changes by comparing two simulation experiments, All_Com and No-LCLUC. Changes in annual NPP and soil carbon storage per unit of fertilizer $\mathrm{N}$ used $\left(\mathrm{g} \mathrm{C} \mathrm{g} \mathrm{N}^{-1} \mathrm{~m}^{-2}\right.$ ) showed continuous decreases in increasing rates of NPP and SOC with intensified fertilizer use in China's croplands from 1980 to 2005, which suggested that the China's agricultural ecosystems might have reached nitrogen saturation (Tian et al., 2011a). 
Other environmental factors. We also considered climate variability/change, atmospheric $\mathrm{CO}_{2}$ and nitrogen deposition, and tropospheric $\mathrm{O}_{3}$ pollution in this study. The combined contributions of these changes to the total NPP and SOC were less than 20\% during 19802005. Both NPP and SOC showed substantial interannual variations in responses to climate variability, similar to the study by Tian et al. (1999). Our results, the direct positive effects of increasing $\mathrm{CO}_{2} /$ nitrogen deposition and the negative effects of elevated $\mathrm{O}_{3}$ on NPP and SOC, were consistent with other reports (e.g. Schindler \& Bayley, 1993; Holland et al., 1997; Aunan et al., 2000; Neff et al., 2000; Felzer et al., 2004; Ren et al., 2007). Some researchers have postulated that these environmental factors could have a greater impact upon the NPP and SOC if the current warming trend continues (e.g. Tao et al., 2009), and elevated $\mathrm{CO}_{2}$ and increased $\mathrm{O}_{3}$ pollution could not be reined (e.g. Felzer et al., 2005).

Interactive effects of multiple stresses. We conducted sensitivity experiments on NPP and found that the effect of a single factor could be enhanced or could be weakened and even the direction of the response could be reversed by its interactions with other environmental factors (Fig. 7). For examples, the single effects of $\mathrm{CO}_{2}$ slightly enhanced NPP about $0 \sim 25 \mathrm{Tg} \mathrm{C} \mathrm{yr}^{-1}$ (Fig. 7a), while the combined effects of $\mathrm{CO}_{2}$ could lead to an increase in NPP about $25 \sim 150 \mathrm{Tg} \mathrm{C} \mathrm{yr}^{-1}$ (Fig. 7b). That is possibly because the effect of elevated $\mathrm{CO}_{2}$, well recognized as fertilizer to increase carbon storage capacity, was enhanced by nitrogen inputs including nigrogen deposition and fertilizer (Reich et al., 2006). In addition, the negative effects of elevated $\mathrm{O}_{3}$ on crop growth were doubled on average when combined with other factors (Fig. 7a and b), which might be caused by climate change (drought) (Ren et al., 2011b) and nitrogen fertilizer (Felzer et al., 2005). Therefore, the overall effects of multiple enviromental stresses on crop production and soil carbon storage are complex, which interactively influence the photosynthesis process, the stomatal conductance, and nutrient/water conditions etc. Many studies (Table 3) have individually explored either positive or negative effects of changing enviromental factors on crop productivity and soil carbon storage during the period 1980-2000, such as the elevated $\mathrm{O}_{3}$ pollution, which reduced crop yields (e.g. reduction rates ranging from $9.1 \%$ to $1.7 \%$ for spring wheat and winter wheat, respectively) and soil carbon storage (3.3 $-3.9 \%)$, and fertilizer use that significantly enhanced the soil carbon storage in the upper 30 centimeters (e.g. increase rates of $11-19 \mathrm{Tg} \mathrm{C} \mathrm{yr}^{-1}$ in 1998 and of 6-16.4 $\mathrm{Tg} \mathrm{C} \mathrm{yr}^{-1}$ in 2005). Our simulation results showed that the combined effects (including elevated $\mathrm{O}_{3}$, increased
$\mathrm{CO}_{2}$, intensified fertilizer use, crop expansion/shrinkage, and others) led to increases in both crop NPP and SOC between 1980 and 2000. This study illuminated the vital importance of considering combined effects of multiple environmental stresses and exploring the underlying mechanisms, which is crucial to better understand the roles of agricultural ecosystems in the global carbon budget and global food security. We thank Jiyuan Liu, Jerry Melillo and John Reilly for their support in the early stage of this work, Mingliang Liu, Chaoqun $\mathrm{Lu}$, Guangsheng Chen and Xiaofeng $\mathrm{Xu}$ for developing input data and the Dynamic Land Ecosystem Model (DLEM), Ge Sun, Art Chappelka, Luke Marzen and two anonymous reviewers for constructive comments.

\section{Acknowledgments}

This study has been supported by NASA Land Cover and Land Use Change Program (NNX08AL73G), NASA Interdisciplinary Science Program (NNG04GM39C), the Ministry of Science and Technology of China (2010CB950604), and the Chinese Academy of Science. We thank Jiyuan Liu, Jerry Melillo and John Reilly for their support in the early stage of this work, Mingliang Liu, Chaoqun Lu, Guangsheng Chen and Xiaofeng Xu for developing input data and the Dynamic Land Ecosystem Model (DLEM), Ge Sun, Art Chappelka, Luke Marzen and two anonymous reviewers for constructive comments.

\section{References}

Aunan K, Berntsen TK, Seip HM (2000) Surface ozone in China and its possible impact on agriculture crop yields. Ambio, 29, 294-301.

Avnery S, Mauzerall DL, Liu JF, Horowitz LW (2011) Global crop yield reductions due to surface ozone exposure: 1 . Year 2000 crop production losses and economic damage. Atmospheric Environment, 45, 2284-2296.

Bondeau A, Smith PC, Zaehle S et al. (2007) Modelling the role of agriculture for the 20th century global terrestrial carbon balance. Global Change Biology, 13, 679706.

Booker F, Muntifering R, McGrath M et al. (2009) The ozone component of global change: potential effects on agricultural and horticultural plant yield, product quality and interactions with invasive species. Journal of Integrative Plant Biology, 51, 337-351.

Cao MK, Woodward FI (1998) Dynamic responses of terrestrial ecosystem carbon cycling to global climate change. Nature, 393, 249-252.

Cao MK, Prince SD, Li KR, Tao B, Small J, Shao XM (2003) Response of terrestrial carbon uptake to climate interannual variability in China. Global Change Biology, 9, 536-546.

Davidson EA, Ackerman IL (1993) Changes in soil carbon inventories following cultivation of previously untilled soils. Biogeochemistry, 20, 161-193.

Farage PK, Long SP, Lechner EG, Baker NR (1991) The sequence of change within the photosynthetic apparatus of wheat following short-term exposure to ozone. Plant Physiology, 95, 529-535.

Farquhar GD, von Caemmerer S, Berry JA (1980) A biochemical model of photosynthetic $\mathrm{CO}_{2}$ assimilation in leaves of $\mathrm{C}_{3}$ species. Planta, 149, 78-90.

Felzer B, Kicklighter D, Melillo J, Wang C, Zhuang Q, Prinn R (2004) Effects of ozone on net primary production and carbon sequestration in the conterminous United States using a biogeochemistry model. Tellus Series B-Chemical and Physical Meteorology, 56, 230-248.

Felzer B, Reilly J, Melillo J et al. (2005) Future effects of ozone on carbon sequestration and climate change policy using a global biogeochemical model. Climatic Change, 73, 345-373.

Godfray HCJ, Pretty J, Thomas SM, Warham EJ, Beddington JR (2011) Linking policy on climate and food. Science, 331, 1013-1014. 
Goetz SJ, Prince SD, Small J, Gleason ACR (2000) Interannual variability of global terrestrial primary production: results of a model driven with satellite observations. Journal of Geophysical Research-Atmospheres, 105, 20077-20091.

Grant RF, Nalder IA (2000) Climate change effects on net carbon exchange of a boreal aspen-hazelnut forest: estimates from the ecosystem model ecosys. Global Change Biology, 6, 183-200.

Guo LB, Gifford RM (2002) Soil carbon stocks and land use change: a meta-analysis. Global Change Biology, 8, 345-360.

Holland EA, Braswell BH, Lamarque JF et al. (1997) Variations in the predicted spatial distribution of atmospheric nitrogen deposition and their impact on carbon uptake by terrestrial ecosystems. Journal of Geophysical Research-Atmospheres, 102, 15849-15866.

Houghton RA (1999) The annual net flux of carbon to the atmosphere from changes in land use 1850-1990. Tellus Series B-Chemical and Physical Meteorology, 51, 298 313

Huang Y, Sun WJ (2006) Changes in topsoil organic carbon of croplands in mainland China over the last two decades. Chinese Science Bulletin, 51, 1785-1803.

Huang Y, Zhang W, Sun WJ, Zheng XH (2007) Net primary production of Chinese croplands from 1950 to 1999. Ecological Applications, 17, 692-701.

Huang Y, Yu YQ, Zhang W et al. (2009) Agro-C: a biogeophysical model for simulating the carbon budget of agroecosystems. Agricultural and Forest Meteorology, 149, 106-129.

Islam KR, Weil RR (2000) Soil quality indicator properties in mid-Atlantic soils as influenced by conservation management. Journal of Soil and Water Conservation, $\mathbf{5 5}$ 69-78.

Janzen HH, Campbell CA, Izaurralde RC, Ellert BH, Juma N, McGill WB, Zentner RP (1998) Management effects on soil C storage on the Canadian prairies. Soil \& Tillage Research, 47, 181-195.

Lal R (2004) Is crop residue a waste? Journal of Soil and Water Conservation, 59, 136a139 a.

Liu ML, Tian HQ (2010) China's land-cover and land-use change from 1700 to 2005: estimations from high-resolution satellite data and historical archives. Global Biogeochemical Cycle, 24, GB3003, doi:10.1029/2009GB003687.

Liu XJ, Zhang FS (2011) Nitrogen fertilizer induced greenhouse gas emissions in China. Current Opinion in Environmental Sustainability, 3, 407-413.

Liu J, Liu M, Tian HQ et al. (2005) Current status and recent changes of cropland in China: an analysis based on Landsat TM data. Remote Sensing Environment, 98, 442 $-456$.

Lloyd J, Taylor JA (1994) On the temperature dependence of soil respiration. Functional Ecology, 8, 315-323.

Lobell DB, Schlenker W, Costa-Roberts J (2011) Climate trends and global crop production since 1980. Science, 333, 616-620.

Lu F, Wang XK, Han B (2009) Soil carbon sequestrations by nitrogen fertilizer application, straw return and no-tillage in China's cropland. Gobal Change Biology, 15, 281 -305 .

Lu CQ, Tian HQ (2007) Spatial and temporal patterns of nitrogen deposition in China: Synthesis of observational data. Journal of Geophysical Research, 112, D22S05, doi:10.1029/2006JD007990.

Lu CQ, Tian HQ, Liu M et al. (2012) Effect of nitrogen deposition on China's terrestrial carbon uptake in the context of multi-factor environmental changes. Ecological Applications, 22, 53-75.

Luo YQ, Weng ES (2011) Dynamic disequilibrium of the terrestrial carbon cycle under global change. Trends in Ecology \& Evolution, 26, 96-104.

Magill AH, Aber JD, Berntson GM, McDowell WH, Nadelhoffer KJ, Melillo JM, Steudler $P$ (2000) Long-term nitrogen additions and nitrogen saturation in two temperate forests. Ecosystems, 3, 238-253.

Martin MJ, Farage PK, Humphries SW, Long SP (2000) Can the stomatal changes caused by acute ozone exposure be predicted by changes occurring in the mesophyll? A simplification for models of vegetation response to the global increase in tropospheric elevated ozone episodes. Australian Journal of Plant Physiology, 27, 211 -219 .

Matson P, Lohse KA, Hall SJ (2002) The globalization of nitrogen deposition: consequences for terrestrial ecosystems. Ambio, 31, 113-119.

Melillo JM, Mcguire AD, Kicklighter DW, Moore B, Vorosmarty CJ, Schloss AL (1993) Global climate-change and terrestrial net primary production. Nature, 363, 234-240.

Murty D, Kirschbaum MUF, McMurtrie RE, McGilvray A (2002) Does conversion of forest to agricultural land change soil carbon and nitrogen? a review of the literature. Global Change Biology, 8, 105-123.

Neff JC, Hobbie SE, Vitousek PM (2000) Nutrient and mineralogical control on dissolved organic $\mathrm{C}, \mathrm{N}$ and $\mathrm{P}$ fluxes and stoichiometry in Hawaiian soils. Biogeochemistry, 51, 283-302.
Nemani RR, Keeling CD, Hashimoto H et al. (2003) Climate-driven increases in global terrestrial net primary production from 1982 to 1999. Science, 300, 1560-1563.

Ollinger SV, Aber JD, Reich PB, Freuder RJ (2002) Interactive effects of nitrogen deposition, tropospheric ozone, elevated $\mathrm{CO}_{2}$ and land use history on the carbon dynamics of northern hardwood forests. Global Change Biology, 8, 545-562.

Paustian K, Andren O, Janzen HH et al. (1997) Agricultural soils as a sink to mitigate $\mathrm{CO}_{2}$ emissions. Soil Use and Management, 13, 230-244.

Paustian K, Cole CV, Sauerbeck D, Sampson N (1998) $\mathrm{CO}_{2}$ mitigation by agriculture: an overview. Climatic Change, 40, 135-162.

Pell EJ, Schlagnhaufer CD, Arteca RN (1997) Ozone-induced oxidative stress: mechanisms of action and reaction. Physiologia Plantarum, 100, 264-273.

Post WM, Kwon KC (2000) Soil carbon sequestration and land-use change: processes and potential. Global Change Biology, 6, 317-327.

Prince SD, Goward SN (1995) Global primary production: a remote sensing approach. Journal of Biogeography, 22, 815-835.

Reich PB, Hobbie SE, Lee T et al. (2006) Nitrogen limitation constrains sustainability of ecosystem response to $\mathrm{CO}_{2}$. Nature, 440, 922-925.

Ren W, Tian HQ, Liu ML et al. (2007) Effects of tropospheric ozone pollution on net primary productivity and carbon storage in terrestrial ecosystems of China. Journal of Geophysical Research, 112, 1-17.

Ren W, Tian HQ, Xu XF et al. (2011a) Spatial and temporal patterns of $\mathrm{CO}_{2}$ and $\mathrm{CH}_{4}$ fluxes in China's croplands in response to multifactor environmental changes. Tellus B, 63, 222-240.

Ren W, Tian HQ, Tao B et al. (2011b) Impacts of tropospheric ozone and climate change on net primary productivity and net carbon exchange of China's forest ecosystems. Global Ecology and Biogeography, 20, 391-406.

Running SW, Nemani RR, Heinsch FA, Zhao MS, Reeves M, Hashimoto H (2004) A continuous satellite-derived measure of global terrestrial primary production. BioScience, 54, 547-560.

Russell AE, Cambardella CA, Laird DA, Jaynes DB, Meek DW (2009) Nitrogen fertilizer effects on soil carbon balances in Midwestern US agricultural systems. Ecological Applications, 19, 1102-1113.

Ryan MG (1991) Effects of climate change on plant respiration. Ecological Applications, 1, 157-167.

Scheller RM, Mladenoff DJ (2007) An ecological classification of forest landscape simulation models: tools and strategies for understanding broad-scale forested ecosystems. Landscape Ecology, 22, 491-505.

Schimel D, Melillo J, Tian HQ et al. (2000) Contribution of increasing $\mathrm{CO}_{2}$ and climate to carbon storage by ecosystems in the United States. Science, 287, 2004-2006.

Schindler DW (2001) The cumulative effects of climate warming and other human stresses on Canadian freshwaters in the new millennium. Canadian Journal of Fisheries and Aquatic Sciences, 58, 18-29.

Schindler DW, Bayley SE (1993) The biosphere as an increasing sink for atmospheric carbon-estimates from increased nitrogen deposition. Global Biogeochemical Cycles, 7, 717-733.

Shi XZ, Yu DS, Warner ED et al. (2004) Soil database of 1:1,000,000 digital soil survey and reference system of the Chinese genetic soil classification system. Soil Survey Horizon, 45, 129-136.

Sun W, Huang Y, Zhang W, Yu Y (2010) Carbon sequestration and its potential in agricultural soils of China. Global Biogeochemical Cycles, 24, GB3001, doi:10.1029/ 2009GB003484.

Tang H, Qiu J, Ranst EV, Li CS (2006) Estimations of soil organic carbon storage in cropland of China based on DNDC model. Geoderma, 134, 200-206.

Tao FL, Yokozawa M, Zhang Z, Xu YL, Hayashi Y (2005) Remote sensing of crop production in China by production efficiency models: models comparisons, estimates and uncertainties. Ecological Modelling, 183, 385-396.

Tao FL, Yokozawa M, Zhang Z (2009) Modelling the impacts of weather and climate variability on crop productivity over a large area: a new process-based mode development, optimization, and uncertainties analysis. Agricultural and Forest Meteorology, 149, 831-850.

Thornley JHM, Cannell MGR (2000) Modelling the components of plant respiration: representation and realism. Annals of Botany, 85, 55-67.

Tian HQ, Melillo JM, Kicklighter DW, McGuire AD, Helfrich J (1999) The sensitivity of terrestrial carbon storage to historical climate variability and atmospheric $\mathrm{CO}_{2}$ in the United States. Tellus Series B-Chemical and Physical Meteorology, 51, 414-452.

Tian HQ, Chen, GS et al. (2010a) Pattern and variation of C:N:P ratios in China's soils: a synthesis of observational data. Biogeochemistry, 98, 139-151.

Tian HQ, Chen G, Liu M et al. (2010b) Model estimates of ecosystem net primary productivity, evapotranspiration, and water use efficiency in the Southern United States during 1895-2007. Forest Ecology and Management, 259, 1311-1327. 
Tian HQ, Melillo J, Lu CQ et al. (2011a) China's terrestrial carbon balance: contributions from multiple global change factors. Global biogeochemical cycles, 25, $1-16$.

Tian HQ, $\mathrm{Xu} X \mathrm{XF}, \mathrm{Lu} \mathrm{CQ}$ et al. (2011b) Net exchanges of $\mathrm{CO}_{2}, \mathrm{CH}_{4}$, and $\mathrm{N}_{2} \mathrm{O}$ between China's terrestrial ecosystems and the atmosphere and their contributions to global climate warming. Journal of Geophysical Research-Biogeosciences, 116, 1-13.

Tian HQ, Chen G, Zhang C et al. (2012) Century-scale response of ecosystem carbon storage and flux to multifactorial global change in the Southern United States. Ecosystems, 15, 674-694.

Tjoelker MG, Volin JC, Oleksyn J, Reich PB (1995) Interaction of ozone pollution and light effects on photosynthesis in a forest canopy experiment. Plant Cell and Environment, 18, 895-905.

Vukicevic T, Braswell BH, Schimel D (2001) A diagnostic study of temperature controls on global terrestrial carbon exchange. Tellus Series B-Chemical and Physical Meteorology, 53, 150-170.

Wang XK, Manning W, Feng ZW, Zhu YG (2007) Ground level ozone in China: distribution and effects on crop yields. Environmental Pollution, 147, 394-400.

Wang CJ, Pan GX, Tian YG, Li LQ, Zhang XH, Han XJ (2010) Changes in cropland topsoil organic carbon with different fertilizations under long-term agro-ecosystem experiments across mainland China. Science China-Life Sciences, 53, 858-867.

Wittig VE, Ainsworth EA, Long SP (2007) To what extent do current and projected increases in surface ozone affect photosynthesis and stomatal conductance of trees? A meta-analytic review of the last 3 decades of experiments. Plant Cell and Environment, 30, 1150-1162.

Wu L, Cai ZC (2007) Estimation of the change of topsoil organic carbon of croplands in China based on long-term experimental data. Ecology and Environment, 16, 17681774.

Xu XF, Tian HQ, Zhang C, Liu ML, Ren W, Chen GS, Lu CQ (2010) Attribution of spatial and temporal variations in terrestrial methane flux over North America. Biogeosciences, 7, 3637-3655.
Yan HM, Cao MK, Liu JY et al. (2005) Characterizing spatial patterns of multiple cropping system in China from multi-temporal remote sensing images. Transactions of the CSAE, 21, 85-90.

Yan HM, Liu JY, Huang HQ, Tao B, Cao MK (2009) Assessing the consequence of land use change on agricultural productivity in China. Global and Planetary Change, 67, 13-19.

Zhang W, Yu YQ, Sun WJ, Huang Y (2007) Simulation of soil organic carbon dynamics in Chinese rice paddies from 1980 to 2000. Soil Science Society of China, 17, 1-10.

Zhang YQ, Yu Q, Jiang J, Tang YH (2008) Calibration of Terra/MODIS gross primary production over an irrigated cropland on the North China Plain and an alpine meadow on the Tibetan Plateau. Global Change Biology, 14, 757-767.

Zhao M, Heinsch FA, Nemani RR, Running SW (2005) Improvements of the MODIS terrestrial gross and net primary production global data set. Remote Sensing of Environment, 95, 164-176.

\section{Supporting Information}

Additional Supporting Information may be found in the online version of this article:

Table S1. Major input data information

Please note: Wiley-Blackwell are not responsible for the content or functionality of any supporting materials supplied by the authors. Any queries (other than missing material) should be directed to the corresponding author for the article. 